\title{
Genetic differentiation in the populations of red piranha, Pygocentrus nattereri Kner (1860) (Characiformes: Serrasalminae), from the river basins of northeastern Brazil
}

\author{
L. A. Luz $^{a}$, L. L. Reis ${ }^{a}$, I. Sampaio ${ }^{b}$, M. C. Barros ${ }^{a, c}$ and E. Fraga ${ }^{a, c}$ \\ aPrograma de Mestrado em Ciência Animal - CMCA, Centro de Ciências Agrárias - CCA, \\ Universidade Estadual do Maranhão - UEMA, Tirirical, s/n, CEP 65058-250, Cidade Operária, São Luís, MA, Brazil

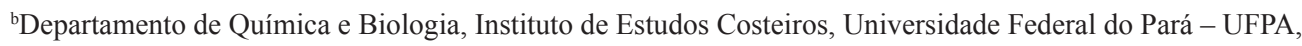 \\ Alameda Leandro Ribeiro, s/n, CEP 68600-000, Aldeia, Bragança, PA, Brazil \\ ${ }^{c}$ Laboratório de Genética e Biologia Molecular, Departamento de Química e Biologia, \\ Universidade Estadual do Maranhão - UEMA, Praça Duque de Caxias, s/n, CEP 65604-380, \\ Morro do Alecrim, Caxias, MA, Brazil \\ *e-mail: lucianaluz_alves@hotmail.com
}

Received: January 17, 2014 - Accepted: July 18, 2014 - Distributed: November 30, 2015

(With 4 figures)

\begin{abstract}
The red piranha, Pygocentrus nattereri, is an important resource for artisanal and commercial fisheries. The present study determines the genetic differentiation among P. nattereri populations from the northeastern Brazilian state of Maranhão. The DNA was isolated using a standard phenol-chloroform protocol and the Control Region was amplified by PCR. The PCR products were sequenced using the didesoxyterminal method. A sequence of $1039 \mathrm{bps}$ was obtained from the Control Region of 60 specimens, which presented 33 polymorphic sites, 41 haplotypes, $\mathrm{h}=0.978$ and $\pi=0.009$. The neutrality tests $(D$ and $F s)$ were significant $(P<0.05)$ for most of the populations analyzed. The AMOVA indicated that most of the molecular variation $(72 \%)$ arises between groups. The fixation index was highly significant $\left(F_{S T}=0.707, P<0.00001\right)$. The phylogenetic analyses indicated that the specimens represented a monophyletic group. Genetic distances between populations varied from $0.8 \%$ to $1.9 \%$, and were $<0.5 \%$ within populations. The degree of genetic differentiation found among the stocks of $P$. nattereri indicates the need for the development of independent management plans for the different river basins in order to preserve the genetic variability of their populations.
\end{abstract}

Keywords: DNA mitochondrial, control region, variability, management, conservation.

\section{Diferenciação genética em populações da piranha vermelha, Pygocentrus nattereri Kner (1860) (Characiformes: Serrasalminae), em bacias hidrográficas do nordeste do Brasil}

\begin{abstract}
Resumo
A piranha vermelha, Pygocentrus nattereri, é um recurso importante para pesca artesanal e comercial. O presente estudo determinou a diferenciação genética entre populações de $P$. nattereri no nordeste do estado brasileiro do Maranhão. O DNA foi isolado utilizando o protocolo de Fenol-clorofórmio e a Região Controle foi amplificada por PCR. Os produtos da PCR foram sequenciados usando o método didesoxiterminal. Uma sequência de 1039 pbs foi obtida da Região Controle de 60 espécimes, que apresentaram 33 sítios polimórficos, 41 haplótipos, $\mathrm{h}=0.978$ e $\pi=0.009$. Os testes de neutralidade $(D$ and $F s)$ foram significativos $(P<0.05)$ para a maioria das populações analisadas. A AMOVA indicou que a maior parte da variação molecular $(72 \%)$ surge entre os grupos. O índice de fixação foi altamente significativo $\left(F_{S T}=0.707\right.$, $P=<0.00001)$. As análises filogenéticas indicaram que os espécimes representam um grupo monofilético. Distâncias genéticas entre as populações variaram de $0.8 \%$ a $1.9 \%$, e de $<0.5 \%$ dentro das populações. O grau de diferenciação genética encontrada entre os estoques de $P$. nattereri indicam a necessidade para o desenvolvimento de planos de manejo independentes para as diferentes bacias hidrográficas, a fim de preservar a variabilidade genética dessas populações.
\end{abstract}

Palavras-chave: DNA mitocondrial, região controle, variabilidade, manejo, conservação. 


\section{Introduction}

Piranhas are Neotropical freshwater fishes, member of the order Characiformes a group of some ten families, 240 genera, and 1460 species found predominantly in the New World - from the southwestern United States and Central America to South America - as well as Africa that present a range of predatory behaviors (Santos et al., 2004; Calcagnotto et al., 2005), specifically the subfamily Serrasalminae, which includes approximately 80 species in 15 genera (Santana et al., 2011). Serrasalmines are present in all the river basins of South America (Oyakawa et al., 2006).

The red piranha, Pygocentrus nattereri Kner (1860), is characterized by its oval-shaped body, convex profile, medium size (up to $25 \mathrm{~cm}$ ), and predominantly dark grayish-silvery coloration, which becomes reddish in the region of the pectoral, ventral, and anal fins. The teeth are resistant, sharp, strong, and dilacerating, which reflects the voracious carnivorous feeding behavior of these fishes (Soares, 2005; Santos et al., 2006). The species is found in a number of different river basins in South America (Queiroz et al., 2010). The ample distribution of the species, its relative abundance, and meaty body contribute to its use as a food by human populations, primarily for soups and sashimi (Barros et al., 2010).

This species is widely distributed in the Brazilian state of Maranhão, which represents an area of transition between the semi-arid region of northeastern Brazil to the east and the exuberant Amazon rainforest to the west, and a complex hydrographic system dominated by perennial rivers such as the Parnaíba, Itapecuru, Mearim, and Pindaré. The Pindaré, Mearim, and Itapecuru form a group of basins typical of the region, with similar topography, and all three discharge into the Gulf of Maranhão, the Mearim/Pindaré into São Marcos Bay, and the Itapecuru in São José Bay. The lower stretches of the Itapecuru and Mearim are characterized by a distinct landscape of meanders and lakes, and the Mearim connects to the Pindaré, which is its principal tributary (Teixeira and Souza-Filho, 2009; Piorski, 2010). The geomorphological evolution of the Gulf of Maranhão reflects the fluctuations in sea level that occurred during the Pliocene and Pleistocene, which culminated in the present-day configuration of estuaries in central Maranhão (Ab’Saber, 1960).

The successful exploitation of the fishery resources available in a river basin depends not only on the understanding of the life cycles of the local species, but also the genetic structure of their populations. Molecular techniques, including sequences of mitochondrial DNA (mtDNA) have proven especially effective for the evaluation of the genetic diversity of a wide range of fish taxa, and the Control Region has been used for the analysis of the population structure of a large number of species (Santos et al., 2004; Calcagnotto et al., 2005; Fraga et al., 2007; Cheng et al., 2012; Borba et al., 2013).

The taxonomy and systematics of the serrasalmines are subject to a great deal of controversy, and there is considerable disagreement on the position of the subfamily in the Characiformes (Santana et al., 2011). A number of studies have raised questions with regard to the phylogenetic relationships among the species of the genus Pygocentrus (Freeman et al., 2007; Hubert et al., 2007; Ortí et al., 2008). Analyzing the phylogeography of $P$. nattereri based on sequences of the Control Region, Torrico (2004) found evidence of population structuring in the specimens from the Madeira River, which formed a distinct group from those collected in the Solimões and Ucayali basins.

Despite its economic and nutritional importance, few data are available on the genetic structure of the P. nattereri populations of the river basins of the Brazilian Northeast, and no information whatsoever exists for the state of Maranhão. As the exploitation of fishery stocks without any prior knowledge of their genetic variability may hamper management initiatives and sustainability, the present study investigated the genetic differentiation of the $P$. nattereri populations of the principal river basins of Maranhão, in northeastern Brazil, based on the sequencing of the mitochondrial Control Region.

\section{Material and Methods}

\subsection{Collection and extraction of DNA}

A total of 60 Pygocentrus nattereri specimens were collected from the basins of the Itapecuru (municipality of Itapecuru-Mirim), Mearim (municipality of Pedreiras), Pindaré (municipality of Pindaré-Mirim), and Parnaíba (municipality of Coelho Neto) rivers in the Brazilian state of Maranhão (Figure 1), with each basin being represented by 15 specimens. The specimens were identified based on the specific literature (Britski et al., 1999; Santos et al., 2004, 2006; Soares, 2005) and confirmed by specialists from the Museum of Zoology at São Paulo University, MZUSP (vouchers - 104549/104550). All specimens were euthanized by immersion in ice water (Ashley, 2007) and deposited in the collection of the Genetics and molecular Biology Laboratory of Maranhão State University in Caxias. Samples of muscle tissue were extracted from each specimen and conserved in $70 \%$ ethanol. The DNA was extracted using the standard phenol-chloroform protocol (Sambrook and Russel, 2001). The collection of specimens was authorized by IBAMA, the Brazilian Federal Environment Institute (license number 02012.004159/2006).

\subsection{PCR and sequencing}

The mitochondrial Control Region was isolated and amplified using the Polymerase Chain Reaction (PCR) based on the primers D-LoopL1 ' 5 CTAACTCCCAAAGCTAGGTATTC3' and D-LoopH1 '5 TGTTTATCACTGCTGRRTTCCCT 3' (Santa Brígida et al., 2007). The PCR was run in a final volume of $25 \mu \mathrm{l}$ composed of $4 \mu \mathrm{l}$ of DNTPs $(1.25 \mathrm{M}), 2.5 \mu \mathrm{l}$ of buffer solution (10X), $0.5 \mu \mathrm{l}$ of $\mathrm{MgCl}_{2}$ solution $(50 \mathrm{mM}), 1 \mu \mathrm{l}$ of DNA $(250 \mathrm{ng} / \mu \mathrm{l}), 0.25 \mu \mathrm{l}$ of each primer $(200 \mathrm{ng} / \mu \mathrm{l})$, $0.2 \mu \mathrm{l}$ of the Taq polymerase enzyme $(5 \mathrm{U} / \mu \mathrm{l})$, and $16.3 \mu \mathrm{l}$ of purified water. 


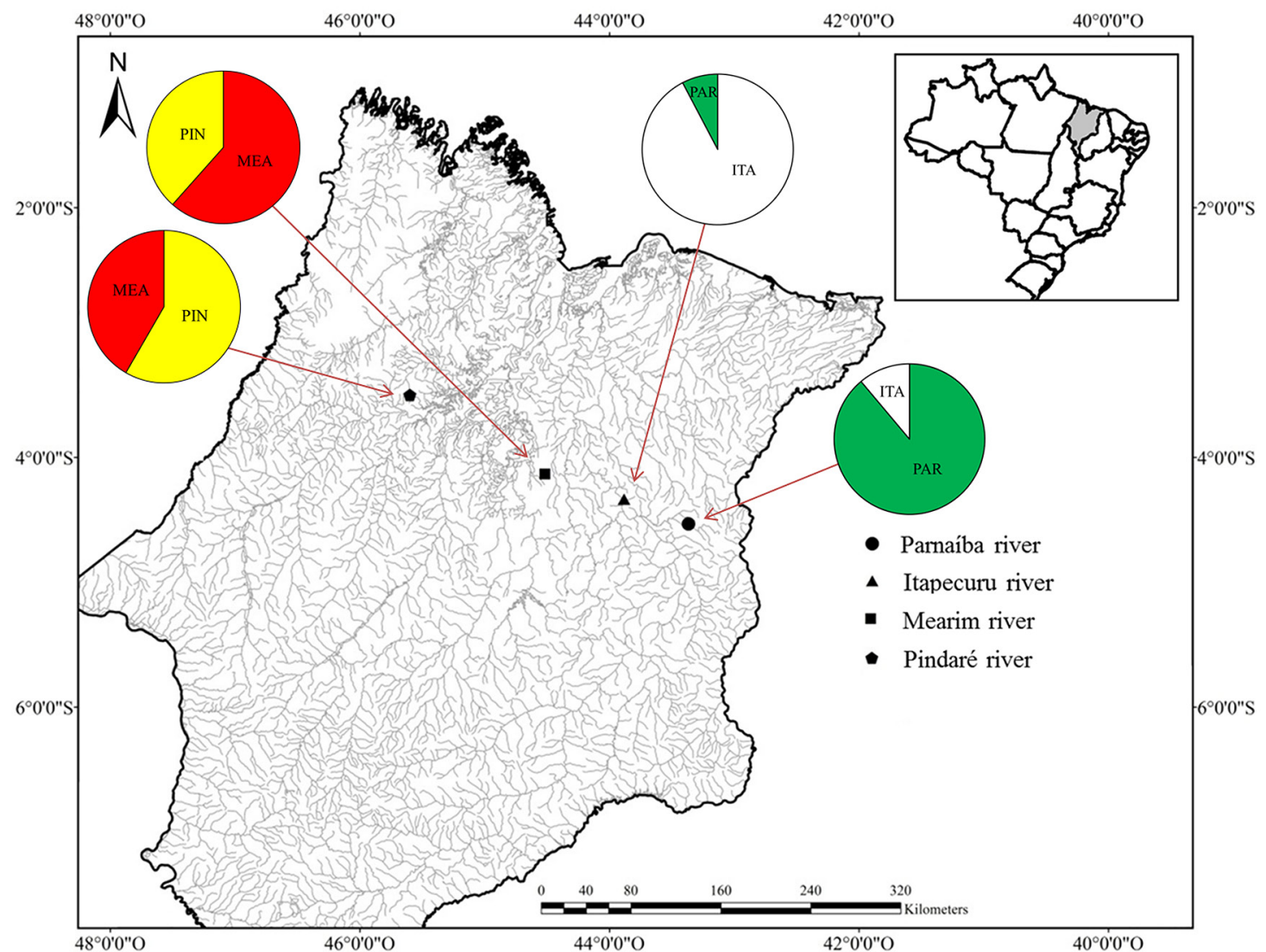

Figure 1. Location of the river basins in the Brazilian state of Maranhão in which the specimens of Pygocentrus nattereri were collected for analysis in the present study. The circles represent the proportion of the haplotypes shared between basins. $\mathrm{PAR}=$ Parnaíba, ITA $=$ Itapecuru, MEA $=$ Mearim, and PIN $=$ Pindaré.

The amplification protocol consisted of $3 \mathrm{~min}$ at $94^{\circ} \mathrm{C}$, followed by 35 cycles of $30 \mathrm{~s}$ at $94^{\circ} \mathrm{C}, 1 \mathrm{~min}$ at $50^{\circ} \mathrm{C}, 2 \mathrm{~min}$ at $72^{\circ} \mathrm{C}$, and a final extension of $7 \mathrm{~min}$ at $72^{\circ} \mathrm{C}$. The PCR products were visualized in a $1 \%$ agarose minigel with ethidium bromide and purified with ExoSAP-IT according to the manufacturer's protocol. The sequencing reaction was based on the Sanger et al. (1977) technique, using an ABI Prism TM Dye Terminator v 3.1 Cycle Sequencing Reading Reaction kit (Applied Biosystems). The samples were precipitated in EDTA/sodium acetate/ethanol and analyzed in an automatic DNA sequencer (ABI 3500/Life Technologies).

\subsection{Phylogenetic and population analyses}

The sequences were edited in Bioedit 7.0 (Hall, 1999) and aligned using the Clustal W 1.4 tool (Thompson et al., 1994). Two sequences of the Control Region of Pygocentrus nattereri deposited in the Genbank (AF283953 - Ortí et al., 2008 and AP012000 - Nakatani et al., 2011) were used as a reference for the alignment. The most adequate evolutionary model for the dataset was identified by JmodelTest 2 (Darriba et al., 2012). Tamura's (1992) T92+G+I model was selected for the construction of the trees using the Akaike Information Criterion (AIC), with the parameters being derived from Maximum Likelihood (ML) and Neighbor-Joining (NJ) approaches. The phylogenetic analyses Maximum Likelihood (ML) and Neighbor-Joining (NJ) were run in PHYML 3.0 (Guindon et al., 2010). The significance of the groupings produced by these analyses was tested by bootstrap analysis with 1000 pseudoreplicates (Felsenstein, 1985). Sequences of Metynnis hypsauchen (D-Loop AF283957 - Ortí et al., 2008) and Metynnis sp. (D-Loop AF283956 - Ortí et al., 2008) were used as the outgroup.

The haplotype and nucleotide diversity indices were obtained from DNAsp 5.1 (Librado and Rozas, 2009), and the haplotype network was generated by Haploviewer software (Salzburger et. al., 2011), using the Maximum Likelihood, in PHYML 3.0 (Guindon et al., 2010). Evidence of selective neutrality in the populations was gleaned from the $D$ (Tajima, 1989) and $F_{S}$ tests (Fu, 1997). The possible existence of differentiated populations and the significance of inter- and intra-population variability were verified using an Analysis of Molecular Variance (AMOVA). Five different AMOVAs were run, four of which included only the populations from Maranhão, and a fifth that included 30 sequences of the Control Region of $P$. nattereri obtained from Genbank, representing populations 
from the basin of the Amazon River (Amazonas, Brazil) - KC132013/ KC131975-79 (Thompson et al., 2014), DQ384773-75 and DQ384781-83 (Hubert et al., 2007), AP012000 (Nakatani et al., 2011) and AF283953 (Ortí et al., 2008), the Madeira River (Amazonas, Brazil) - DQ384764-72 (Hubert et al., 2007), the Paraná River (Paraná, Brazil) - DQ384776-80 (Hubert et al., 2007), and the São Francisco River (Bahia, Brazil) - DQ384784-85 (Hubert et al., 2007). The fixation index $\left(F_{S T}\right)$ and its significance were obtained from 1023 random permutations. The neutrality tests of AMOVA and fixation indices were obtained in the Arlequin 3.5 program (Excoffier and Lischer, 2010). Possible population groups were identified in BAPS 6.0 using the Bayesian grouping analysis described by Corander et al. (2013). The nucleotide divergence indices were determined by the uncorrected $p$ distances and the corrected Tamura and Nei (1993) parameters in Mega 6.0 (Tamura et al., 2013) considering the groups generated in the BAPS analysis.

\section{Results}

The amplification of the Control Region of the 60 Pygocentrus nattereri specimens generated a sequence of 1039 base pairs. The mean nucleotide composition of these sequences was 29.8\% Thymine, 23.4\% Cytosine, 30.6\% Adenine, and $16.2 \%$ Guanine. A total of 33 polymorphic sites and 41 haplotypes were identified, with a general haplotype diversity of 0.978 and nucleotide diversity of 0.009 . High levels of haplotype diversity were found in each of the populations analyzed (Table 1).

Overall, 32 of the 41 haplotypes identified in the analyses were unique and exclusive. Of these, seven (H2-H5 and H7-H9) were from the Parnaíba basin, 12 (H10-H21) were from the Itapecuru, eight (H23, H24, H28-H32, and $\mathrm{H} 34$ ) were from the Mearim, and the remaining five (H36-H39 and H41) were from the Pindaré. The most common haplotype was H6, which was recorded six times and was found in both the Parnaíba and Itapecuru basins. The second most common haplotype was $\mathrm{H} 1$, which was exclusive to the Parnaíba, with five records. The third most common haplotype was H26, with a total of four records from the Mearim and Pindare basins, while the fourth most common was also found in these two basins, with a total of three records. Three other haplotypes -
$\mathrm{H} 22, \mathrm{H} 27$, and $\mathrm{H} 33$ - were also recorded from these two basins, with one record from each. The other haplotypes with two records - H35 and H40 - were exclusive to the Pindaré River (Figure 2).

The haplotype network (Figure 2) revealed a higher degree of similarity between the specimens from the Parnaíba and Itapecuru basins, even though one group of haplotypes from the Parnaíba is separated from the Itapecuru by three mutation events. The specimens from the Mearim and Pindaré basins were also highly similar, and were differentiated from the Parnaíba and Itapecuru populations by 12 mutations. These findings were further reinforced by the analyses of genetic distance ( $p$ distance, and Tamura and Nei), with distances of up to $1.9 \%$ between the Parnaíba population and that of Mearim-Pindaré, and $1.4 \%$ between Itapecuru, Mearim-Pindaré.

The results of the neutrality tests - Tajima's $D$ and Fu's $F_{S}$ - were significant $(P<0.05)$ for the majority of the populations (except for the Parnaíba River $-F s=-0.976$, $P=0.283$ ) when analyzed together or separately (Table 1). This indicates that the hypothesis of neutral polymorphism can be rejected, and suggests that the populations passed through a recent process of expansion.

The patterns of genetic variability found within and between populations in the Analysis of Molecular Variance

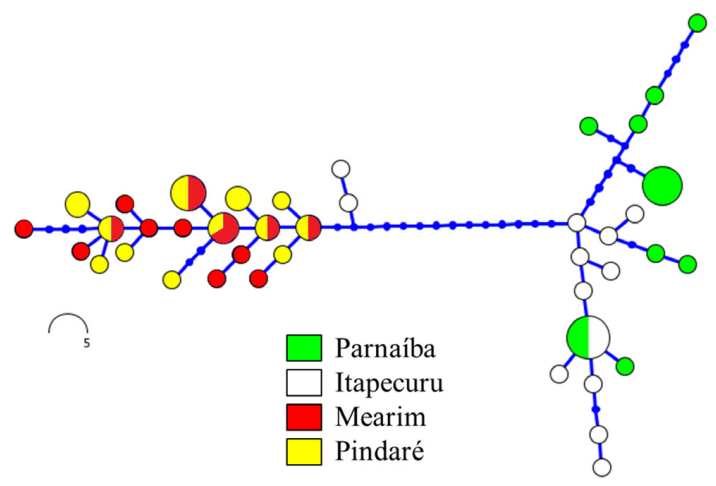

Figure 2. Haplotype network based on a maximum likelihood analysis of the sequences of the mitochondrial Control Region. Each haplotype is represented by a circle (the size of which is proportional to its total frequency in the populations) with the different colors representing each of the study populations.

Table 1. Levels of genetic diversity and the results of the neutrality tests for the populations of Pygocentrus nattereri from the Brazilian state of Maranhão analyzed in the present study, based on sequences of the mitochondrial Control Region.

\begin{tabular}{ccccccccc}
\hline & & & \multicolumn{3}{c}{$\begin{array}{c}\text { Index of molecular } \\
\text { diversity }\end{array}$} & \multicolumn{3}{c}{ Neutrality tests } \\
\cline { 5 - 9 } Population & $\mathbf{N}$ & NH & $\mathbf{S}$ & $\mathbf{h}$ & $\boldsymbol{\pi}$ & \multicolumn{1}{c}{$\mathbf{D}$} & \multicolumn{1}{c}{$\mathbf{F}_{\mathbf{s}}$} & $\mathbf{P}$ \\
\hline Parnaíba river & 15 & 09 & 14 & 0.876 & 0.005 & 0.840 & -0.976 & 0.283 \\
Itapecuru river & 15 & 13 & 18 & 0.971 & 0.005 & -0.022 & -6.072 & 0.001 \\
Mearim river & 15 & 13 & 09 & 0.981 & 0.002 & -0.008 & -10.55 & 0.000 \\
Pindaré river & 15 & 12 & 09 & 0.971 & 0.002 & -0.188 & -8.503 & 0.000 \\
Total & 60 & 41 & 33 & 0.978 & 0.009 & 0.155 & -6.527 & 0.071 \\
\hline
\end{tabular}

$\mathrm{N}$ = sample size; $\mathrm{NH}=$ number of haplotypes, $\mathrm{S}=$ polymorphic sites; $h=$ haplotype diversity, $\pi=$ nucleotide diversity, $D=$ Tajima's index, $F_{S}=$ Fu's index, and $P=$ significance of the $F_{S}$ value. Significance level $(P<0.05)$. 
(AMOVA) were based on the three principal clusters, i.e., Parnaíba, Itapecuru, and Mearim/Pindaré. The AMOVA indicated that $72 \%$ of the molecular variation was found among groups, with only $29 \%$ being found within populations. The $F_{S T}$ value was 0.707 , and highly significant $(p<0.00001)$, indicating the existence of genetic structuring among the study populations (Table 2). When the populations were considered as a single group, the differentiation among populations was $68 \%$, and the $F_{S T}$ value $(0.667)$ was still highly significant $(p<0.00001)$. Three other simulations were run on the Maranhão populations (Parnaíba vs. Mearim-Pindaré, Itapecuru vs. Mearim-Pindaré and Parnaíba, Itapecuru vs. Mearim-Pindaré), and the results were always $F_{S T}<0.70$ with $p<0.00001$.

The results of the AMOVA that included the 30 P. nattereri sequences obtained from Genbank, and tested the hierarchy of three groups - North (Amazon and Madeira basins), South (Paraná River), and Northeast (Parnaíba, Itapecuru, Mearim, Pindaré and São Francisco basins) - found that most $(46 \%)$ of the molecular variation is found among populations of the same region. The $F_{S T}$ value was 0.716 , with a highly significant $p(<0.00001)$, indicating the existence of a high degree of genetic structuring among populations (Table 2).

The phylogenetic analyses were based on two different approaches - ML and NJ - in order to estimate the most likely topology of the evolutionary history of the $P$. natterer $i$ populations in the study area. Both methods produced highly similar topologies, grouping the specimens with $100 \%$ bootstrap values. The different phylogenetic approaches (Figure 3) also revealed the existence of three distinct groups formed by the specimens from the Parnaíba basin (ML and NJ with $85 \%$ bootstrap values), samples from the Parnaíba and Itapecuru rivers $(\mathrm{ML}=69 \%, \mathrm{NJ}=84 \%)$, and specimens from the Itapecuru, Mearim, and Pindaré basins ( $M L=92 \%, \mathrm{NJ}=95 \%)$.

The population groupings generated by the BAPS analysis, based on Bayesian inference, revealed the existence of three groups or clusters (Parnaíba, Itapecuru, and Mearim-Pindaré), with the greatest distance being found between the Parnaíba and Mearim-Pindaré groups, with a divergence of $1.9 \%$ (Figure 4 , Table 3 ). The smallest divergence $(0.8 \%)$ was found between the Parnaíba and Itapecuru groups, while within-population differentiation was invariably less than $0.5 \%$ (Table 3 ).

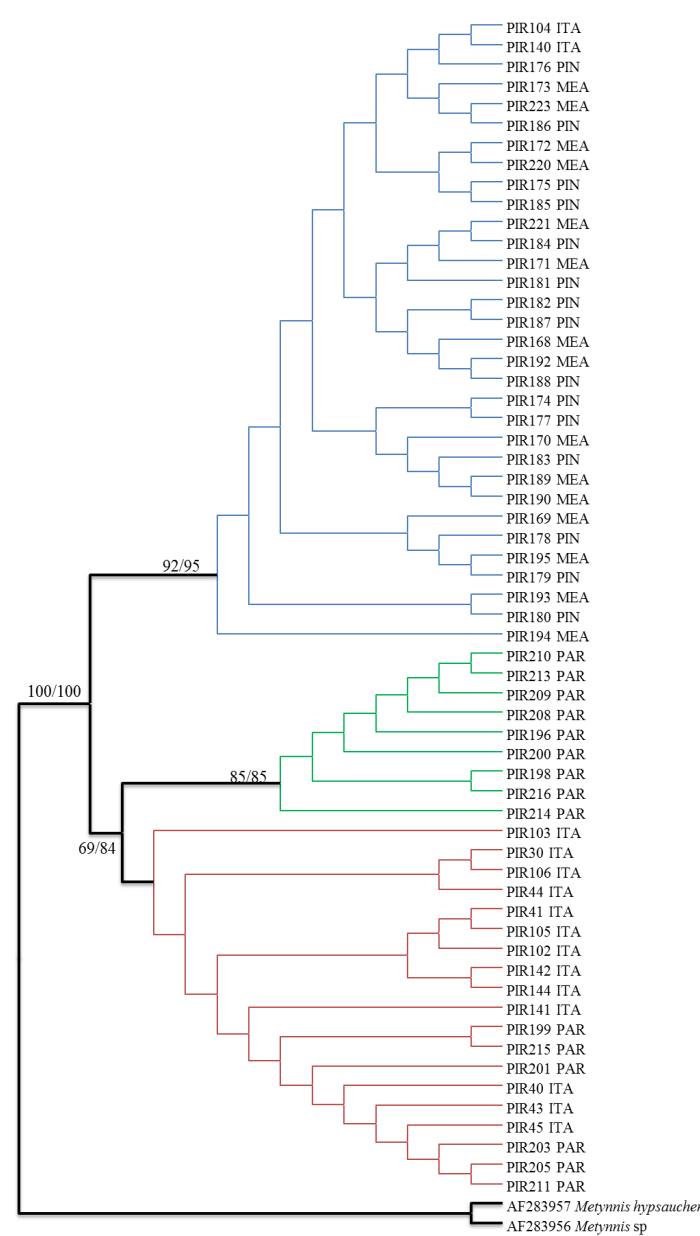

Figure 3. Phylogenetic tree derived from 1000 bootstrap replicates based on the Tamura (1992) model. The numbers above the branches represent the bootstrap values for the Maximum Likelihood/Neighbor-Joining approaches, respectively. PAR $=$ Parnaíba, ITA $=$ Itapecuru, MEA $=$ Mearim, and PIN $=$ Pindaré

Table 2. Results of the AMOVA for the populations of Pygocentrus nattereri obtained for the sequences of the mitochondrial Control Region.

\begin{tabular}{|c|c|c|c|c|c|}
\hline Type of variation & Component of & riation & $\begin{array}{c}\% \text { of the total } \\
\text { variation }\end{array}$ & $\mathbf{F}_{\mathrm{ST}}$ & $\mathbf{P}$ \\
\hline \multicolumn{6}{|c|}{ Clusters: Parnaíba, Itapecuru and Mearim-Pindaré } \\
\hline Betw & ups & 4.932 & 72 & 0.707 & $<0.00001$ \\
\hline Between populati & he same groups & -0.072 & -1 & & \\
\hline Within & tions & 2.014 & 29 & & \\
\hline \multicolumn{6}{|c|}{ Groups: North, South and Northeast } \\
\hline Betw & ups & 129.617 & 26 & 0.716 & $<0.00001$ \\
\hline Between populati & he same groups & 189.116 & 46 & & \\
\hline Within & tions & 154.667 & 28 & & \\
\hline
\end{tabular}

Significance level $(P<0.05)$. 
Table 3. Mean nucleotide divergence (percentage) among Pygocentrus nattereri populations from the Brazilian state of Maranhão based on $p$ (below the diagonal) and Tamura and Nei (above the diagonal) distances.

\begin{tabular}{cccccc}
\hline \multirow{2}{*}{ Population } & \multicolumn{3}{c}{ \% Inter-population divergence } & \% Intra-population \\
\cline { 2 - 4 } & Parnaíba & Itapecuru & Mearim-Pindaré & & divergence \\
\hline Parnaíba & & 0.8 & 1.9 & 0.3 \\
Itapecuru & 0.8 & & 1.5 & 0.2 \\
Mearim-Pindaré & 1.9 & 1.4 & & 0.3 \\
\hline
\end{tabular}

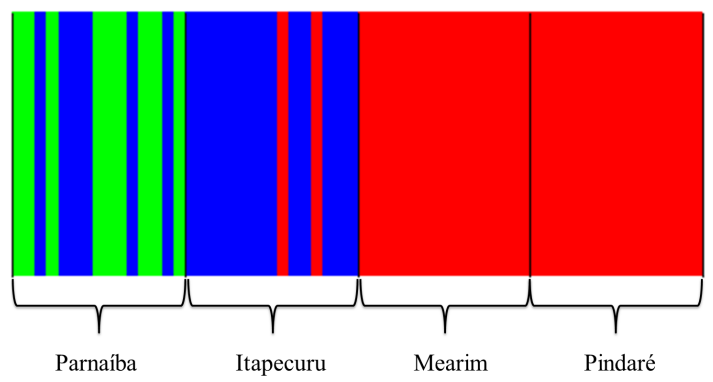

Figure 4. A priori estimate of the probable groups of populations produced by the BAPS (Bayesian Analysis of Population Structure v 6.0) program, indicating a total of three groups.

\section{Discussion}

In the present study, the estimates of polymorphism in Pygocentrus nattereri indicated high levels of genetic variability in the river basins analyzed. Haplotype diversity was high considering the populations either as a group ( $h=0.978$ ) or individually. The genetic variability of a population may determine its capacity to adapt to changes in the environment, reproductive success and growth rates and, ultimately, its chances of survival over the long term (Frankham et al., 2002).

The haplotype network indicated a greater genetic similarity between the specimens from the Mearim and Pindaré basins, emphasized by the largest number of shared haplotypes (five). This marked similarity between the basins was further emphasized by the results of the BAPS analysis, with the two groups being included in a single cluster. The genetic proximity between the specimens from these two basins may be a result of their geomorphological similarities, and not least because the Pindaré is the principal tributary of the Mearim (Teixeira and Souza-Filho, 2009; Piorski, 2010).

The neutrality tests $-D$ (Tajima, 1989) and $F_{S}(\mathrm{Fu}, 1997)$ - were significant $(P<0.05)$ for most populations, indicating that they may have passed through a recent process of expansion. This conclusion is supported by the large number of unique haplotypes found in these populations, given that rapid population growth favors the retention of new mutations (Avise et al., 1984).

The results of the AMOVA indicated that the majority $(72 \%)$ of the genetic variation was related to differences among the groups. The highly significant $F_{S T}$ value ( 0.707 ; $p<0.00001)$ indicated that the $P$. nattereri populations are genetically structured. A similar pattern was observed in the populations from the Northern, Northeastern and Southern regions $\left(F_{S T=} 0.716 ; p<0.00001\right)$. Defining genetic variation at the population level is essential for the understanding of the distribution of this diversity within the species. When this variation is continuous, any given area within its geographic range should be representative of the species, whereas genetic structuring indicates the need to consider each subpopulation as a separate unit (Terencio, 2009).

The phylogenetic analyses based on the different analytical approaches (ML and $\mathrm{NJ}$ ) and with bootstrap values of $100 \%$, indicated the existence of three distinct groups (Parnaíba, Itapecuru-Parnaíba, and Mearim-Pindaré). The concept of evolutionary units refers to the definition of a population or group of populations differentiated genetically, morphologically or ecologically from neighboring conspecific populations, reflecting a historical process of geographic isolation on some level. As they present distinct characteristics, these groups should be treated as independent units for conservation purposes (Terencio, 2009). Torrico (2004) reported that the $P$. nattereri specimens from the upper Madeira, Solimões, and Ucayali Rivers grouped together with a 100\% bootstrap value. Ortí et al. (2008) also confirmed the monophyletism of the serrasalmines based on an analysis of the mitochondrial Control Region. Similar results were obtained using this marker for the serrasalmine genera Serrasalmus (Hubert et al., 2007) and Pygocentrus (Freeman et al., 2007).

The highest genetic divergence indices between populations were found between Parnaíba and Mearim/Pindaré (1.9\%). Low levels of divergence $(<0.5 \%)$ were found within the populations analyzed. Hubert et al. (2007) recorded genetic distances of $1.2 \%$ and $3.0 \%$ between serrasalmine species, and distances of $0.1 \%$ to $0.8 \%$ between populations of the same species. In a phylogeographic study of $P$. nattereri, Torrico (2004) recorded divergence values of between $0.29 \%$ and $1.12 \%$ for specimens from the Madeira, Ucayali, and Solimões river basins. Analyzing the Control Region, Ortí et al. (2008) recorded genetic distances of $0.017 \%$ to $0.256 \%$ between serrasalmine species.

The definition of biological parameters is extremely important for the development of adequate procedures for the management of natural resources, such as fishery stocks. Studies of genetic variability, principally those based on polymorphisms of mitochondrial DNA, provide a strong scientific baseline for the development of conservation and management programs (Batista, 2010). 
In the present study, the results of the analysis of the Control Region provided important insights into the genetic variability of the Pygocentrus nattereri populations of the study area, and in particular, their structuring among the different river basins revealed consistently by the different analytical approaches, all of which supported the presence of three distinct groups (Parnaíba, Itapecuru, and Mearim-Pindaré). These findings will be important for the development of effective conservation and management policies, which should treat each basin separately, given the genetic differences found between them.

\section{Acknowledgements}

We are grateful to the Bank of Northeastern Brazil (BNB) and the Maranhão State Scientific and Technological Development Foundation (FAPEMA) for financial support. We would also like to thank Luís Fernando Silva Rodrigues, a post-doctoral fellow at the Institute of Coastal Studies at UFPA/Bragança campus for conducting the analyses.

\section{References}

AB'SÁBER, A.N., 1960. Contribuições à geomorfologia do Estado do Maranhão. Notícia Geomorfolóica, vol. 3, no. 5, pp. 35-49. Transcrito do Anuário da Faculdade de Filosofia.

ASHLEY, P.J., 2007. Fish welfare: current issues in aquaculture. Applied Animal Behaviour Science, vol. 104, no. 3-4, pp. 199-235. http://dx.doi.org/10.1016/j.applanim.2006.09.001.

AVISE, J.C., NEIGEL, J.E. and ARNOLD, J., 1984. Demographic influences on mitochondrial DNA lineage survivorship in animal populations. Journal of Molecular Evolution, vol. 20, no. 2, pp. 99-105. http://dx.doi.org/10.1007/BF02257369. PMid:6433037.

BARROS, L.A., MATEUS, L.A.F., BRAUM, D.T. and BONALDO, J., 2010. Aspectos ecológicos de endoparasitos de piranha vermelha (Pygocentrus nattereri, Kner 1860) proveniente do rio Cuiabá. Arquivo Brasileiro de Medicina Veterinária e Zootecnia, vol. 62 , no. 1 , pp. 228-231. http://dx.doi.org/10.1590/S010209352010000100033 .

BATISTA, J.S., 2010. Caracterização genética da douradaBrachyplatystoma rousseauxii, Castelnau, 1855 (Siluriformes: Pimelodidae) na Amazônia por meio de marcadores moleculares mitocondriais e microssatélites: subsídios para conservação e manejo. Amazonas: Instituto Nacional de Pesquisa da AmazôniaINPA. 128 p. Tese de Doutorado em Conservação e Biologia Evolutiva.

BORBA, R.S., SILVA, E.L., PONZETTO, J.M., POZZOBON, A.P.B., CENTOFANTE, L., ALVES, A. and PARISE-MALTEMPI, P.P., 2013. Genetic structure of the ornamental tetra fish species Piabucus melanostomus Holmberg, 1891 (Characidae, Iguanodectinae) in the Brazilian Pantanal wetlands inferred by mitochondrial DNA sequences. Biota Neotropica, vol. 13, no. 1, pp. 42-46. http://dx.doi.org/10.1590/S1676-06032013000100004.

BRITSKI, H.A., SILIMON, K.Z.S. and LOPES, B.S., 1999. Peixes do Pantanal: manual de identificação. Corumbá-SP: Embrapa. 184 p.

CALCAGNOTTO, D., SCHAEFER, S.A. and DESALLE, R., 2005. Relationships among Characiformes fishes inferred from analysis of nuclear and mitochondrial gene sequences. Molecular
Phylogenetics and Evolution, vol. 36, no. 1, pp. 135-153. http:// dx.doi.org/10.1016/j.ympev.2005.01.004. PMid:15904862.

CHENG, Y.Z., XU, T.J., JIN, X.X., TANG, D., WEI, T., SUN, Y.Y., MENG, F.Q., SHI, G. and WANG, R.X., 2012. Universal primers for amplification of the complete mitochondrial control region in marine fish species. Molecular Biology, vol. 46, no. 5, pp. 727-730. http://dx.doi.org/10.1134/S0026893312040024. PMid:23156681.

CORANDER, J., CHENG, L., MARTTINEN, P., SIRÉN, J. and TANG, J. 2013. BAPS: Bayesian Analysis of Population Structure. Finland: University of Helsinki. 28 p. Manual version 6.0.

DARRIBA, D., TABOADA, G.L., DOALLO, R. and POSADA, D., 2012. jModelTest 2: more models, new heuristics and parallel computing. Nature Methods, vol. 9, no. 8, pp. 772. http://dx.doi. org/10.1038/nmeth.2109. PMid:22847109.

EXCOFFIER, L. and LISCHER, H.E.L., 2010. Arlequin suite ver. 3.5: a new series of programs to perform population genetics analyses under Linux and Windows. Molecular Ecology Resources, vol. 10 , no. 3, pp. 564-567. http://dx.doi.org/10.1111/j.17550998.2010.02847.x. PMid:21565059.

FELSENSTEIN, J., 1985. Confidence limits on phylogenies: an approach using the bootstrap. Evolution, vol. 39, no. 4, pp. 783-791. http://dx.doi.org/10.2307/2408678.

FRAGA, E., SCHNEIDER, H., NIRCHIO, M., SANTABRIGIDA, E., RODRIGUES-FILHO, L.F. and SAMPAIO, I., 2007. Molecular phylogenetic analyses of mullets (Mugilidae, Mugiliformes) based on two mitochondrial genes. Journal of Applied Ichthyology, vol. 23, no. 5, pp. 598-604. http://dx.doi. org/10.1111/j.1439-0426.2007.00911.x.

FRANKHAM, R., BALLOU, J.R. and BRISCOE, D.A., 2002. Introduction to conservation genetics. Cambridge: Cambridge University Press. $640 \mathrm{p}$

FREEMAN, B., NICO, L.G., OSENTOSKI, M. and COLLINS, H.L., 2007. Molecular systematic of Serrasalmidae: Deciphering the identities of piranha species and unraveling their volutionary histories. Zootaxa, vol. 1484, pp. 1-38.

FU, Y.X., 1997. Statistical tests of neutrality of mutations against population growth hitchhiking and background selection. Genetics, vol. 147, no. 2, pp. 915-925. PMid:9335623.

GUINDON, S., DUFAYARD, J.F., LEFORT, V., ANISIMOVA, M., HORDIJK, W. and GASCUEL, O., 2010. New algorithms and methods to estimate maximum-likelihood phylogenies: assessing the performance of PhyML 3.0. Systematic Biology, vol. 59, no. 3, pp. 307-321. http://dx.doi.org/10.1093/sysbio/ syq010. PMid:20525638.

HALL, T.A., 1999. BioEdit: a user-friendly biological sequence alignment editor and analysis program for Windows 95/98/NT. Nucleic Acids Symposium Series, vol. 41, pp. 95-98.

HUBERT, N., DUPONCHELLE, F., NUÑEZ, J., GARCIA-DAVILA, C., PAUGY, D. and RENNO, J.F., 2007. Phylogeography of the piranha genera Serrasalmus and Pygocentrus: implications for the diversification of the Neotropical ichthyofauna. Molecular Ecology, vol. 16, no. 10, pp. 2115-2136. http://dx.doi.org/10.1111/j.1365294X.2007.03267.x. PMid:17498236.

LIBRADO, P. and ROZAS, J., 2009. DNAsp v5: a software for comprehensive analyses of DNA polymorphism data. Bioinformatics, vol. 25, no. 11, pp. 1451-1452. http://dx.doi. org/10.1093/bioinformatics/btp187. PMid:19346325. 
NAKATANI, M., MIYA, M., MABUCHI, K., SAITOH, K. and NISHIDA, M., 2011. Evolutionary history of Otophysi (Teleostei), a major clade of the modern freshwater fishes: Pangaean origin and Mesozoic radiation. Evolutionary Biology, vol. 11, pp. 177. PMid:21693066.

ORTÍ, G., SIVASUNDAR, A., DIETZ, K. and JÉGU, M., 2008. Phylogeny of the Serrasalmidae (Characiformes) based on mitochondrial DNA sequences. Genetics and Molecular Biology, vol. 31, no. 1, pp. 343-351. http://dx.doi.org/10.1590/ S1415-47572008000200030.

OYAKAWA, O.T., AKAMA, A., MAUTARI, K. C. and NOLASCO, J. C., 2006. Peixes de riachos da Mata Atlântica nas unidades de conservação do Vale do Rio Ribeiro de Iguarapé no estado de São Paulo. São Paulo: Editora Neotropica. 201 p.

PIORSKI, N.M., 2010. Diversidade genética e filogeografia das espécies Hoplias malabaricus (Bloch, 1794) e Prochilodus lacustris Steindachner, 1907 no Nordeste do Brasil. São Carlos: Universidade Federal de São Carlos. 153 p. Tese de Doutorado em Genética e Evolução.

QUEIROZ, H.L., SOBANSKI, M.B., MAGURRAN, A.E. and QUEIROZ, H.L., 2010. Reproductive strategies of Red-bellied Piranha (Pygocentrus nattereri Kner, 1858) in the white waters of the Mamirauá flooded forest, central Brazilian Amazon. Environmental Biology of Fishes, vol. 89, no. 1, pp. 11-19. http:// dx.doi.org/10.1007/s10641-010-9658-1.

SALZBURGER, W., EWING, G.B. and VON HAESELER, A., 2011. The performance of phylogenetic algorithms in estimating haplotype genealogies with migration. Molecular Ecology, vol. 20, no. 9, pp. 1952-1963. http://dx.doi.org/10.1111/j.1365294X.2011.05066.x. PMid:21457168.

SAMBROOK, J. and RUSSEL, D.W., 2001. Molecular cloning: a laboratory manual cold spring harbor laboratory press. New York: Cold Spring Harbor.

SANGER, F., NICKLEN, S. and COULSON, A.R., 1977. DNA sequencing with chain termination inhibitors. Proceedings of the National Academy of Sciences of the United States of America, vol. 74, no. 12, pp. 5463-5467. http://dx.doi.org/10.1073/ pnas.74.12.5463. PMid:271968.

SANTA BRÍGIDA, E.L., CUNHA, D.B., REGO, O.S., SAMPAIO, I., SCHNEIDER, H. and VALLINOTO, M., 2007. Population analysis of Scomberomorus cavalla (Perciformes, Scombridae) from the Northern and Northeastern coast of Brazil. Revista Brasileira de Biologia = Brazilian Journal of Biology, vol. 67, no. 4, suppl, pp. 919-924. http://dx.doi.org/10.1590/S151969842007000500016. PMid:18278360.

SANTANA, M.P., GIONGO, P., TRAVENZOLI, N.M., WALKER, N.J. and SAMPAIO, W.M.S., 2011. Diversidade cariotípica da piranha vermelha Pygocentrus nattereri (Characiformes, Characidae) rio Salobo, bacia do Araguaia, Pará, Brasil. Evolução e Conservação da Biodiversidade, vol. 2, no. 1, pp. 98-103.
SANTOS, G.M., FERREIRA, E. and ZUANON, J., 2006. Peixes comerciais de Manaus. 2nd ed. Manaus: Ibama-ProVárzea.

SANTOS, G.M., MÉRONA, B., JURAS, A.A. and JÉGU, M., 2004. Peixes do Baixo Rio Tocantins: 20 anos depois da Usina Hidrelétrica Tucuruí. Brasília: Eletronorte. 216 p.

SOARES, E.C., 2005. Peixes do Mearim. São Luís: Instituto Geia. 142 p.

TAJIMA, F., 1989. Statistical method for testing the neutral mutation hypothesis by DNA polymorphism. Genetics, vol. 123, no. 3, pp. 585-595. PMid:2513255.

TAMURA, K. and NEI, M., 1993. Estimation of the number of nucleotide substitutions in the control region of mitochondrial DNA in humans and chimpanzees. Molecular Biology and Evolution, vol. 10, no. 3, pp. 512-526. PMid:8336541.

TAMURA, K., 1992. Estimation of the number of nucleotide substitutions when there are strong transition-transversion and $\mathrm{G}+\mathrm{C}$ content bases. Molecular Biology and Evolution, vol. 9, no. 4, pp. 678-687. PMid:1630306.

TAMURA, K., STECHER, G., PETERSON, D., FILIPSKI, A. and KUMAR, S., 2013. MEGA6: Molecular Evolutionary Genetics Analysis Version 6.0. Molecular Biology and Evolution, vol. 30, no. 12, pp. 2725-2729. http://dx.doi.org/10.1093/molbev/ mst197. PMid:24132122.

TEIXEIRA, S.G. and SOUZA-FILHO, P.W.M., 2009. Mapeamento de ambientes costeiros tropicais (golfão Maranhense, Brasil) utilizando imagens de sensores remotos orbitais. Revista Brasileira de Geofisica, vol. 27, no. 1, pp. 69-82.

TERENCIO, M.L., 2009. Estimativa da variabilidade genética da região controle do DNA mitocondrial de Nannostomus eques (Characiformes, Lebiasinidae) da bacia do rio Negro. Amazonas: Instituto Nacional de Pesquisa da Amazônia-INPA. 86 p. Dissertação de mestrado em Conservação e Biologia Evolutiva.

THOMPSON, A.W., BETANCUR, R.R., LÓPEZ-FERNÁNDEZ, H. and ORTÍ, G., 2014. A time-calibrated, multi-locus phylogeny of piranhas, pacus, and allies (Characiformes: Serrasalmidae) and a comparison of species tree methods. Molecular Phylogenetics and Evolution, vol. 81, pp. 242-257. http://dx.doi.org/10.1016/j. ympev.2014.06.018. PMid:25261120.

THOMPSON, J.D., HIGGINS, D.J. and GIBSON, T.J., 1994. CLUSTAL W: improving the sensitivity of progressive multiple sequence alignment through sequence weighting, position-specific gap penalties and weight matrix choice. Nucleic Acids Research, vol. 22, no. 22, pp. 4673-4680. http://dx.doi.org/10.1093/ nar/22.22.4673. PMid:7984417.

TORRICO, J.P., 2004. Filogeografia comparada de siete especies de peces de agua dulce del Alto Madeira (Amazonía Boliviana). Bolívia: Universidad Mayor de San Andrés. 95 p. Dissertação de mestrado em Ciências Biológicas y Biomédicas. 